\title{
Ecosystems Transformation and Assessment of Bird Resources in the Republic of Tatarstan (Russia)
}

\author{
Ilgizar Rakhimov ${ }^{1}$, Kadrya Ibragimova ${ }^{2}$ \\ ${ }^{1}$ Kazan (Volga region) Federal University, 420008, Kazan, Russia \\ ${ }^{2}$ Associate professor, Kazan (Volga region) Federal University, 420008, Kazan, Russia
}

\begin{abstract}
The intensification of economic activities, wide scales of the destruction of the woods, the growth of the areas of the worked lands, creation of water basins, urbanization and other forms of transformation of natural landscapes for last centuries have essentially changed the conditions of animals' habitation. 305 species of birds can be found within the territory of Tatarstan. We performed an analysis of the state of the ornithofauna over the past 120 years, which allowed us to get estimates of species density and distribution in the republic. The research material is a gain to the knowledge about ornithofauna of Tatarstan, the state of each species populations and may be used to develop a regional monitoring system.
\end{abstract}

\section{Introduction}

Among the problems facing to ornithology, the major is preservation of biological diversity. It has found reflexion in the program and declarations of United Nations Conference on Environment and Development (Rio de Janeiro, 1992) about preservation of biological diversity, Governmental decree of the Russian Federation «On Procedure of governmental accounting, the state cadastre and the state monitoring of fauna objects».

Nowadays the opinion of native scientists about strengthening of the regional faunistic researches has got wide spread, which is directed on preservation of a biodiversity and creation of faunistic cadasters. During epoch of intensive anthropogenous influence on fauna, including birds, death of many species, serious reorganizations in communities have forced to realize that biodiversity preservation was one of aspects of a sustainable development of a modern society and the major principle of nature protection activity.

The pattern of anthropogenic factors influence on ornithological complexes in Tatarstan has increased over the past century due to certain reasons. The key factor of changes in the avifauna of the Middle Volga region is an intensive human economic activity. The processes related to the active development of the region's territory cause disruptions of avifauna. As a result of deforestation and tilling of wild land, creation of reservoirs, growth and expansion of urban settlements, the prevalence of monocultures in agriculture, significant expansion of windbreaker areas, as well as creation of even-aged monoculture forest plantations, open pits, the landscape of Tatarstan has changed significantly. Now the most of its territory is represented by "cultivated forest plantations" [1], with a complex mosaic of scattered spots of dark coniferous, broad-leaved and pine forests, alternated with secondary birch grove and aspen wood. The 
remainders of former zonal vegetation types, allopatric due to human activity. Tessellation of landscapes, diversity of habitats contributes to fluctuation of natural habitat of many species. Non-periodic fluctuations of faunal boundaries of certain bird species in the context of anthropogenic transformation of natural systems are scrutinized by ornithologists. Small populations of birds in forest outlier, once numerous in natural wildlife habital areas, now leave them, then repopulate once again.

Revealing of the laws of avifauna complexes formation, reaction of some species to the anthropogenous influences, in this connection forecasting of the close and remote consequences of these processes, the development of the regulation measures of mutual relations of the mankind and birds in anthropogenous landscapes are actual problems of ornithological researches.

\section{Methods}

The Republic of Tatarstan is located in the middle Volga basin and forms part of the Russian plain. There are no high mountains there, it has rather smooth relief: broad flat watersheds alternate with shallow, well-developed river valleys. The main natural green areas of the Republic of Tatarstan are forest and forest-steppe. Forests cover about $17 \%$ of the entire territory. The main types of planted forest are represented by conifer and leaf forest. The Middle Volga region is located in the transition zone from taiga forests to forest-steppe, which determines bird species diversity in Tatarstan.

The authors have been conducting targeted research and collecting material for more than 40 years. During the expedition trips to different regions of the Middle Volga region, observations were made on the avifauna, its species and quantitative structure, spatial distribution, and ecology of individual species and groups of birds. Fauna and the population of birds were studied by repeated routing accounts in the territories with various degree and character of anthropogenous transformation: in nature reserves, in water basins, in agrolandscapes and settlements. Reliability of nesting was defined according to the criteria, which were recommended by Committee of the European Ornithological Atlas (The EBCC Atlas of European breeding birds, 1997). Nesting considered to be proved when there were found nests, lying of eggs, baby birds, and meetings of flights, i.e. an actual material. Nesting with demonstration by birds of the elements of nested behavior was considered as the probable: singing, gathering of a nested material, forage transportation, etc. Birds' summer staying in suitable conditions for nesting has allowed to consider that birds were probably nesting.

The general extent of constant routes has made $285 \mathrm{~km}$, there were passed about 10 thousand $\mathrm{km}$. There were held supervision over flight and daily movings of birds. There were defined the basic laws of spatial distribution of nesting populations.

\section{Results}

Resettlement of some of bird species across anthropogenic landscapes is a relatively recent phenomenon that can be observed over large areas even within the life-span of one generation, which cannot be compared with any of the known natural processes in terms of speed and outcomes of the said changes. For the Middle Volga region, a collared turtledove illustrates this model, having settled quickly enough in vast areas [2]. A similar process is currently observed with a black redstart.

On January 15, 2009, the State Council of the Republic of Tatarstan adopted the framework nature conservation law "Environmental code of the Republic of Tatarstan", which defined the prospects of a regional strategy for rational nature management and nature protection. The Chapter 6, Article 122 Wildlife Conservation defines the main task of State control in the field 
of wildlife protection, including state registration and maintenance of the state cadastre and state monitoring of wildlife objects [3]. This monitoring of wildlife objects is impossible without specific materials on quantitative assessment of animal resources. This task determined the relevance and significance of the research.

For the first time, the estimates of the number of 305 birds' species inhabiting Tatarstan were obtained, the status of their habitation was determined and clarified, while the last reports on the avifauna of Tatarstan were dated 2001 [4]. The status of nesting habitats was determined based on biotope analysis of the territory of Tatarstan, the structure and distribution of its land fund and the conducted research on model territories and routes. The state of study of certain species and ecological groups of birds in the Republic of Tatarstan is assessed. The directions of avifauna formation in Tatarstan and the prospects for preserving birds' diversity in the region are presented.

\section{Discussion}

Multi-year research in the territory of the republic allowed us to get data on birds' population and to identify trends in changes in some of avifauna forms. Following the analysis of available data for the last 120 years, several groups of species have been identified in the territory of the Republic of Tatarstan, having the following population indicators.

1. Increasing population or they are more seen within the territory of Tatarstan. For such species, like swift Apus apus, sky lark Alauda arvensis, greenish warbler Phylloscopus trochiloides, great-crested grebe Podiceps cristatus, this is due to the expansion of nestable biotopes areas. The population of common partridge Pedrix pedrix, listed in the first edition of the Red data book of the Republic of Tatarstan, has increased and this species was removed from the list of rare and protected avifauna forms [5]. This group also includes species that populated Tatarstan in recent decades, for example, Black redstart Phoenicurus ochruros, Eurasian penduline tit Remiz pendulinus. This group includes 36 species of birds, including Egretta alba, Cygnus olor, Anas platyrhynchos, Milvus migrans, Accipiter nisus, Buteo buteo, Crex crex, Fulica atra, Larus ridibundus, Asio otus, Garrulus glandarius, Acrocephalus arundinaceus, Sylvia atricapilla, Erithacus rubecula, Chloris chloris, Carpodacus erythrinus etc.

2. The next group is bird species with stable population over the past decades (may be either low or high). Low population is observed in most bird of prey, for example, owls (Accipiter gentilis, Pernis apivorus, Aquila rapax, Falco tinnunculus, Glaucidium passerinum, Strix uralensis). High population is observed in most titmouses, finches. The group includes 117 species, such as: Anser albifrons, Anser fabalis, Anas acuta, Aythya ferina, Lyrurus tetrix, Porzana porzana, Tringa nebularia, Actitis hypoleucos, Xenus cinereus, Limosa limosa, Larus argentatus, Chlidonias nigera, Columba livia, Cuculus canorus, Dendrocopos major, Picoides tridactylus, Riparia riparia, Anthus trivialis, Motacilla flava, Corvus cornix, Corvus corax, Acrocephalus dumetorum, Phylloscopus trochilus, Regulus regulus, Muscicapa striata, Luscinia luscinia, Parus major, Fringilla coelebs, Spinus spinus, Acanthis cannabina, Emberiza citrinella etc.

3. A group with a declining population or they are less seen within Tatarstan. These species are the matter of particular concern and require additional protection measures. The main reason for such changes is intensive economic activity. The processes related to the active development of the region's territory cause disruptions of avifauna [6]. As a result of deforestation and tilling of wild land, creation of reservoirs, growth and expansion of urban settlements, the prevalence of monocultures in agriculture, significant expansion of windbreaker areas, as well as creation of even-aged monoculture forest plantations, open pits, the landscape of Tatarstan has changed significantly. We can observe a mosaic of scattered spots of dark coniferous, broad-leaved and pine forests, alternated with secondary birch grove and aspen wood. Studies conducted in 
various forests of Tatarstan showed a significant reduction in cavity nesting birds number in the young forest stands. The group includes 63 species. They are Yellow-breasted blinding Emberiza aureola, Greylag goose Anser anser, Hen-harrier Circus cyaneus, House-sparrow Passer domesticus. For this reason, Greylag goose is listed in Red data book of the Republic of Tatarstan [7]. This group includes: Botaurus stellaris, Anas crecca, Cygnus cygnus, Circaetus gallicus, Circus aeruginosus, Aquila chrysaetos, Falco subbuteo, Falco vespertinus, Otis tarda, Numenius arquata, Chlidonias hybrida, Columba oenas, Bubo bubo, Asio flammeus, Strix aluco, Alcedo atthis, Dryocopus martius, Hirundo rustica, Delichon urbica, Sturnus vulgaris, Corvus frugilegus, Cinclus cinclus, Locustella naevia, Turdus viscivorus, Parus cianus etc.

4. A small group of birds with fluctuating population. It was observed in 20 species, including: Buteo lagopus, Lagopus lagopus, Streptopelia decaocto, Nyctea scandiaca, Loxia curvirostra, Pyrrula pyrrula, Bombycilla garrulus etc. Natural factors are the reason for population fluctuations, mainly related to feeding and weather conditions.

5. The last group includes 70 species with an unclear trend due to poor study of species and lack of information about the population within Tatarstan. This group is represented by small rare species that can be included in the list of protected birds of Tatarstan: Gavia stellate, Pelecanus crispus, Rufibrenta ruficollis, Clangula hyemalis, Melanitta nigra, Mergus merganser, Circus macrourus, Accipiter badius, Porzana parva, Porzana pusilla, Glareola nordmanni, Syrrhaptes paradoxus, Anthus hodgsoni, Prunella montanella, Phyllo Scopus inornatus, Pinicola enucleator, Emberiza leucocephala etc. Many of them are listed in the last edition of the Red data book of the Republic of Tatarstan, for example, red-necked grabe Podiceps grisegena, gerfalcon Falco rusticolus.

Thus, the main reasons for changes in quantitative figures are anthropogenic factors that affect the animals' habitat and their feeding. The most severe impact of anthropogenic factors on natural ecosystems of Tatarstan was in the last 100-120 years. The following changes have occurred over the past period of record:

- As far anthropogenic landscapes grew and developed, their fauna grew and developed, too.

- Settling of birds in anthropogenic-transformed territories was due to ecological advantages of the anthropogenic landscape, besides, natural areas were included in the anthropogenic landscape with their fauna.

- A number of bird species actively settled in urbanized territories and formed urban populations: Great tit, Gray crow, Fieldfare, Linnet, White wagtail, Common wheatear, Lesser whitethroat.

- Both in the past and now, synanthropic species that traditionally inhabit anthropogenic landscapes laid the basis of bird population.

- The creation of reservoirs, deforestation, creation of agrocenoses, urbanization of the region and other forms of economic impact on natural ecosystems have significantly affected the state of avifauna in the Middle Volga region.

- The process of anthropogenic territories population with species formely extrinsic to the region will continue, perhaps, in the near future such species as Common serin, Syrian woodpecker and others will appear in the Middle Volga region.

\section{Conclusion}

The obtained estimate data on the number of birds in Tatarstan allow us to identify the main research and practical directions for formation of most preferable human and bird relationships in terms of intensive anthropogenic impact on natural complexes. The solution of this issue lies in scientific management of both the number and behavior of birds. Primarily it considers dominant species of economic importance, mainly for agriculture. The results obtained shall be 
used in a wide range of environmental measures, primarily for long-term monitoring, as a database for formation of designated conservation areas of Tatarstan.

\section{References}

1. V.D. Ilyichev Practical use and protection of birds in the South Ural region (1983)

2. K.N. Blagosklonov Geography and ecology of terrestrial vertebrates, 3 (1978)

3. The Environmental Code of the Republic of Tatarstan, Kazan (2015)

4. I.I. Rakhimov Avifauna of the Middle Volga in the conditions of anthropogenic transformation of natural landscapes, Kazan (2002)

5. The Red Book of the Republic of Tatarstan. Kazan (2006)

6. V.M.Konstantinov, W.Nowicki, A.G. Pichurin, Acta ornithological, 31 (1996)

7. The Red Book of the Republic of Tatarstan. Kazan (2016) 